\title{
Clara Ursitti: Scents of a Woman
}

\author{
Jim Drobnick
}

Jim Drobnick étudie les auvres de Clara Ursitti dont les installations et performances présentent des odeurs, en particulier les odeurs corporelles, de façon intense et inévitable. En collaborant avec un chimiste et un parfumeur, l'artiste a synthétisé des odeurs de différentes parties de son corps afin de créer un autoportrait olfactif. Cette œuvre conteste le dénigrement culturel des odeurs et cherche à accepter le corps et ses processus naturels.

It all adds up to this, that when the hideous specter of body odour looms, all human ties are canceled. The offender, whether parent, spouse, or friend, puts himself outside the law. And when lovely woman stoops to B.O., she is a Medusa freezing every male within sniff.

- Marshall McLuhan

Despite the intensity and frequency of appeals by soap manufacturers and arbiters of social indiscretions, the battle to deodorize the body completely is ultimately futile, with only provisional victories. This fragrant fact of existence has emerged in a number of artistic explorations in recent years, especially as artists create works foregrounding the body and its physiological processes. Given the antipathy towards bodily odours, artists addressing such a matter necessarily transgress what is considered a significant element of social decorum, if not an outright taboo. How can such despised and supposedly vile emanations be the subject matter of (or medium for) artistic practice? In this article, I will examine several artworks by Clara Ursitti, whose olfactory installations and performances feature body odour in intense and inescapable manners.

Each person has an unremovable and unique scent, variously called an "odour print" (Engen), "olfactory passport" (Vroon) or "smell-face" (Sacks). Helen Keller termed this individuality "person-scent" and noted an integral link between body, personality and odour: 
Some people have a vague, unsubstantial odor that floats about, mocking every effort to identify it. It is the will-o'-the-wisp of my olfactive experience. Sometimes I meet one who lacks a distinctive person-scent, and I seldom find such a one lively or entertaining. On the other hand one who has a pungent odor often possesses great vitality, energy and vigor of mind. (qtd. in Synnott 188)

The link between identity and one's smell is thought by Corbin to have begun at what he calls the "olfactory revolution," the time at which an intolerance to odours erupted during the late-eighteenth century. Along with other indicators related to the rise of individualism, such as new concepts of personal space, time for reflection and reverie (in writing diaries and autobiographies or in reading novels), and the expunging of excrement from public discourse and experience, Corbin proffers that the "odors of the ' $\mathrm{I}$ ' were better defined, more intensely felt." Instead of wearing a "scented mask" such as was the prior custom of using musk-based scents, "the individual atmosphere revealing the uniqueness of the ' $\mathrm{I}$ ' must be allowed to break through" $(61,72)$.

Studies have shown that the ability to recognize another's odour is not limited to extraordinary persons; family members, lovers and close friends are typically capable of distinguishing articles of clothing worn by intimates from a range of random individuals (Schleidt 42-44). Even the security industry is taking advantage of this biological feature by developing artificial noses to scan a person's hand for its specific "olfactory password." "Scentinel," a system which reads and digitally records body odours, operates on the logic that an individual's body part, in this case, scent, cannot be forged or stolen (Davis).

This biological essentialism may be only recently "proven," but it has had a mythic dimension long before technology became sophisticated enough to provide confirmation. For instance, Classen et al. discuss the prevalence of the "association of smell, breath and life" as the index of identity in non-Western and pre-modern societies:

Smells are both carried on the breath and taken in by the breath as it provides life-giving air to the body. Body fluids, also commonly associated with the life force, all have distinctive odours as well. These bodily odours, emanating as they do from the interior of a person, give the impression of conveying the person's essence, or essential being. (116) 
These notions of essence and identity, in both vitalistic and legalistic senses, permeate Clara Ursitti's series of artworks, Self-Portraits in Scent. Collaborating with chemist and parfumier Dr. George Dodd, Ursitti has isolated and synthesized the scents produced from specific parts of her body, such as the vagina, armpit, scalp and feet. Dispensed in electronically activated ventilation booths, discreetly diffused into gallery atmospheres, or offered to visitors on swatches of blotting paper, she aims "to create in the room a feeling of something having been there that was living and breathing" (Ursitti, Artist's Statement 85).

The first self-portrait, Eau Claire (1993), was produced organically by the artist collecting vaginal and menstrual secretions and securing them in a solution of alcohol and coconut oil. Ursitti's bottled concoction instantiates a near-oxymoron - what may be called a "human perfume." Clear Water, in its first incarnation, resembles a do-it-yourself science experiment, which indeed characterizes the artist's process. The second version is modelled upon the more traditional presentation of perfume, with handblown glass replacing the original Mason jars and copper tubing. This version would not look out of place in a parfumerie, except for the lack of product name or identifying insignia. Unsuspecting sniffers may be startled by the fleshy odour, but there is a daring irony in that Ursitti returns perfume to its unsublimated origins: rather than masking a human smell with facsimile secretions from the animal world - drawn from the glands of cats, deer, beavers, and so on - Eau Claire honours body odour in and of itself.

For some, vaginal odour is a prominent source of self-loathing and hatred of the body. Fear and anxiety over the possibility of offending others is so strong that Germaine Greer typified the psychological state as one being frightened "into believing that what lies between our legs is rotting meat" (38). For Susan Brownmiller, the double standard in regard to body odour is all too evident: men can accommodate all manners of foul aromas - sweat, beer, tobacco - without diminishing the masculine mystique, and which may even enhance virility. "No work that a woman does," however, "can enhance her aroma, for femininity exists on a plane of enchantment where the air is rarefied and sweet" (151). She continues,

I've heard too many nasty jokes, I suppose, like the one about the blind man who tips his hat and says "Good morning, ladies," when he passes a fish market. Dread that the female scent needs a mask for sex- 
ual confidence is frankly exploited in commercials for vaginal deodorants, or feminine-hygiene sprays as they are called euphemistically. (Perhaps not so euphemistically. Hygiene refers to the practice of health and cleanliness; in the context of a douchelike product, the word conveys the age-old charge against women, "Unclean, unclean.") (152)

The plethora of euphemisms notwithstanding, vaginal odour was considered so beyond public discourse that overt mention of it did not occur in Western literature until Henry Miller's 1922 Tropic of Capricorn (Corbin 246). Kate Millet argues that Miller's discussion (that "cunt stinks"), rather than fostering acceptance of the body's natural odours, merely articulated male hostility towards sexuality and confirmed the misogynistic disgust and contempt with which women are regarded (Synnott 199-200). Turning women against their bodies is not confined to novels, but is a mainstay of the cosmetic and toilet industries, especially as it pertains to odour. One deodorant ad warned women to "double check your charm everyday" because (in a phrase surprisingly apropos to Ursitti's work) "you are the very air he breathes" (Hoy 171). Greer, leader of an "anti-VD" (vaginal deodorant) campaign, chastised profiteering corporations and marketers for "inventing the problem (at one and the same instant as its solution) of vaginal odour. ... After all, it's not as if the streets had been littered with those overcome by vaginal fumes" (qtd. in Synnott 199-200). Such thinking is still alarmingly prevalent. In Hoffman's discussion of prenuptial agreements and wealthy men's restrictions over their bride's physical condition after marriage, she notes that along with confidentiality, sexual demands, pets and weight gain, some contracts list fines for "spousal belching and flatulence."

Reversing the abject status of the female body and reclaiming its processes and experiences has been a fundamental tenet of feminist and lesbian political and aesthetic practice. Beyond the much-discussed and controversial use of central core imagery in women's art to make the vagina visible and bring it into everyday discourse (Jones), smelling the vagina has been a means to demonstrate Greer's call for "cunt positive" discourse and an affirmation of "cunt-power" (74-77). For instance, Carolee Schneemann conceptualized a pleasure arcade called The Genitals Play - Erotic Meat Room filled with interactive genital sculptures with lifelike textures and aromas. The sensations could be enjoyed by either gen- 
der, in polymorphous combinations, thus affirming total visceral and olfactory pleasure. Schneemann's pro-sex celebration seeks to liberate the body from puritanical restraints and somatophobia. Contrary to Freud's excoriation of the sense of smell, the odours of the genitals do not bring about civilization's fall and a descent into animality, but playfully explore the body's libidinal potential.

The smell of the vagina, however, does not only have to be erotically charged. Holly Hughes features a retrospective conversation between her and her mother in the performance World Without End (1989) in which the parent asks "Do you want to know where babies come from? .. . Are you ready for the meaning of life?" and proceeds to demonstrate "the hidden room where we stash our gold":

Mama says, "Holly, if something's bothering you, and you want to know the answer to it, just remember the answer is inside you." And with that she reached inside herself and then she took her hand out and oh! I could see how wet she was! And that smell! Let me tell you about that smell! That smell made me want to do the mashed potato! Just me and my mother, my naked mother, dancing in the split-level. (19-20)

Here vaginal smell serves as a complex repository of uniquely female experience - a source not only of individuality, but of self-knowledge, strength, esteem, transgenerational communion, and otherwise indefinable joy.

In Eve Ensler's The Vagina Monologues, the range of responses to the question "What does a vagina smell like?" conveys a multitude of meanings just by the variety of descriptive words and phrases:

Earth. Wet garbage. God. Water. A brand-new morning. Depth. Sweet ginger. Sweat. Depends. Musk. Me. No smell, I've been told. Pineapple. Chalice essence. Paloma Picasso. Earthy meat and musk. Cinnamon and cloves. Roses. Spicy musky jasmine forest, deep, deep forest. Damp moss. Yummy candy. The South Pacific. Somewhere between fish and lilacs. Peaches. The woods. Ripe fruit. Strawberrykiwi tea. Fish. Heaven. Vinegar and water. Light, sweet liquor. Cheese. Ocean. Sexy. A sponge. The beginning. (77-79) 
And in Simone Forti's artist's book, Angel, the choreographer muses about smell and its connection to elemental phenomena: "Sometimes when sitting crosslegged a girl ponders the fragrance rising suddenly from her sex as of bread baking but more of the ocean, more of protein, as of shrimps fresh in their shells" (13). Once liberated from the always-already pathologizing effects of hygiene commercials, patriarchal medicine and social fears, other meanings may arise - ones that are positive, humorous, celebratory and profound.

While smell in these works exists conceptually and textually, Ursitti's olfactory self-portrait enacts vaginal smell experientially. For the artist, her body odour is presented "where it does not belong" (in pristine gallery spaces) so that if visitors find it unattractive (in the place designed for aesthetic contemplation) they will hopefully inquire why they do so (Artist's Statement 85). A tense ambiguity thus underlies Ursitti's intentions, one which depends upon the foundation of perceptual stillness provided by the gallery at the same time that it disturbs such perceptual stillness (see my "Reveries, Assaults and Evaporating Presences"). The works are not simply meant to change people's perception of body odour from "bad" to "good"; they rely upon a sense of dislocation, a shock of unexpected intimacy one might say, which inevitably brings up issues concerning the ideology of hygiene, the origin of social taboos concerning the body and odour, the distinctions between the private and public realms, even pornography and the obscene.

Ursitti's self-portraits abolish distance. She reports a differential reaction to the scents that is generally split along gender lines. Men tended to respond negatively, expressed their disgust overtly to the artist, while women reacted positively. Cultural differences also emerged: Britons were generally silent and shied away from the artist, Hungarians came up to sniff her scalp and make their own comparisons between her and the olfactory self-portrait replicating its smell, Netherlanders commended her on her bravery (Interview). And, recently, the artist experienced her first act of "scentsorship" when a gallery director, tired of one work's smell, covered the odour diffuser with a cardboard box and placed a cut onion on a plate in front of it (Ursitti's Email to the Author).

As much as Ursitti's olfactory self-portraits incorporate objects or constructions, which may define them as some form of sculpture or architecture, they operate more like performance. Phelan's definition of performance as "representation without reproduction," that is, a form of 
presencing that does not leave material evidence for commodification or co-optation, is very much like Ursitti's work in that it references the corporeal without actually showing a body. The immediacy of the odours in these works, if not avoiding representation altogether (the title prepares its audience), at least frustrates and challenges types of representations of women that can be all too easily reappropriated (Wolff). By presenting an experience of "woman" outside of the conventions of those forms of representations that are usually marshalled to construct femininity, Ursitti forces her audience to engage in a self-conscious discursive process in which interpretation is not already rationalized and habitual, and responsibility is left to viewers themselves.

Other works in the series carry the subtitle "Sketch" because they are made from synthesized, rather than organic, materials. Through the laboratory techniques of chromatography, secretions are broken down into their composite compounds and their percentages discerned. The olfactory self-portraits are called "sketches" because the technology is not sophisticated enough to identify or synthesize all of the aromatic chemicals constituting one's body odour, which may number in the hundreds. George Dodd, her collaborator, sniffs, analyzes and makes educated guesses about the constituents of the smells on various parts of the artist's body. Self-Portrait in Scent: Sketch \#1 (1994), for instance, lists its ingredients matter-of-factly:

propionic acid, butyric acid, iso-valeric acid, acetic acid, heptatonic acid, 2-methyl acetonic acid, putresine, trimethyle amine, heptane thiol, carbon disulphite, marcapto ethanol, iso-eugenol, acetones, androstene dieneone, skatole.

There is a certain fascination in this clinical recitation of chemicals. Its complexity inspires no small sense of awe to those who toiled to isolate and identify these molecules. Its reductiveness is also refreshing - that such a vigorously scapegoated substance as body odour can be the simple result of several dozen compounds, that "offensiveness" may be due only to a particular combination of chemicals. Reflecting state-of-the-art scientific analysis, this list to some degree demystifies the phenomenon of body odour. The argument has been made by Susan Sontag that once science has stepped in to identify the causes of a physiological or medical condition (as with tuberculosis), all forms of mythologizing, romanticization, 
moral condemnation, etc., fall away. Yet, because the constituents of body odour can be differentiated, they can, of course, theoretically be reconstituted, modulated, remixed (as in any formula for perfume). Such technical information may engender a new level of obsessive bodily self-maintenance, feeding into the already burgeoning toiletry industry with another line of personal care products and olfactory self-management (for a discussion of the artist's olfactory dating service, see my "Inhaling Passions: Art, Sex and Scent").

Ursitti's scientistic description of body odour's chemical composition counters those who consider it abject, as well as those who consider it the elixir of "the charming grotto." Compare her list with, for instance, the list of ingredients by which the murderous parfumier in Patrick Süskind's novel Perfume creates a human odour disguise: cat droppings, vinegar, salt, decomposing cheese, rancid fish oil, rotten egg, castoreum, ammonia, nutmeg, horn shavings, singed pork rind and civet (182-3). Ursitti's list thus places body odour on two separate and seemingly irreconcilable registers: conceptual and experiential. Knowledge of the chemical composition defeats to some degree the horror and the attraction of body odour, yet experiencing it so fully and concentratedly in the gallery tends to evoke even more extreme visceral reactions.

Ursitti's self-portraits re-evaluate notions of bodily presence and representation. They are a continuation of what could be called (with apologies to Rosalind Krauss) "self-portraiture in the expanded field." Conventional self-portraits center upon the face as the primary bearer of identity and seek to isolate and foreground those features which are characteristic of the individual. The logics of likeness and recognizability, however, are the very terms that self-portraits in the modernist era subvert. Identity is based less on visual realism than on more subjective terms: the individual's expressiveness or vitality, or a sense of emotional or psychological "truth." And in postmodernism, the notion of a "real" self is indefinitely postponed in favour of one that is ever provisional, constantly performative, always already imbricated within a system of intertextuality and ideology.

The "expanded" field of self-portraiture both reflects a crisis of individuality and intentionally exacerbates it. The face may be de-privileged, yet other body fragments, physical traces, and oblique corporeal references fill in the vacuum left behind: analyses of bodily excretions, vocal recordings, blood samples, brain and heart rhythms, magnified cells, sonograms, $x-$ 
rays, hypnotic interrogations, dream analyses, astrological profilings, internal cameras, and so on (see, for example, Independent Curators Incorporated). Many of the artworks in this expanded field make compelling use of signs of individuality based on involuntary physical processes, indices of the self that are ephemeral, idiosyncratic, and unassimilable (or yet to be assimilated) into a comprehensive or systemic logic. The foregrounding of the physically intimate and corporeal, in many of these works, emerges from a desire to bypass not only the conscious control of the individual, but the instrumental and rationalized demarcations of the self prevalent in society. Against the constructions of self in highly mediated forms, the corporeal is a method to re-access the natural, the immediate, the undeniably concrete. Self-portraits in the expanded field instantiate what Michel Foucault terms a refusal of identity:

[T]he target nowadays is not to discover what we are, but to refuse what we are.... We have to imagine and to build up what we could be to get rid of ... the simultaneous individualization and totalization of modern power structures. . . We have to promote new forms of subjectivity through the refusal of this kind of individuality which has been imposed on us for several centuries. (216)

Yet this refusal is not without its irony. Ursitti's self-portraits exude a double paradox: first because they posit the existence of a unique self by the foregrounding of one's individual odour signature, yet they also frustrate that uniqueness because such accurate sensing of a broad range of olfactory identities is generally beyond our ability to discriminate; and second because, as a strong odour, they materialize the body in an aggressively intimate fashion, yet at the same time they utterly dematerialize it. Ursitti presents a void where a person or representation should be, what might be called a "hallucination of nothing" (Kristeva 42).

Insofar as her isolated body smells fragment any sense of the wholeness or completeness that narcissism (and self-portraits) reputedly provide, Ursitti's work dispels narcissism (in the psychoanalytic sense of the word). The olfactory sketches flaunt their incompleteness and stage the self as that which is impossible to ascertain by the gaze - either in whole or in part. In testing the limits of representation, Ursitti posits a multiplicity rather than singularity of the body. This self-portrait fails to cohere, for what the medium of this artwork does not have is clear-cut boundaries. It, 
in fact, brings into experience what is lost in the visual rendering of the self, the invisible, so to speak. Body odour - the unseen - destabilizes visualist notions of the self as a discrete entity. Bodily boundaries are replaced by thresholds, shapes by intensities, thingness by a dispersed, transient presence.

Given the low level of discrimination with which the sense of smell is endowed in Western culture, how are the ambiguous semiotic valences of smell to be read? Do we interpret Ursitti's self-portrait as an index, a sign, a trace, or all three? The scent is obviously a synecdoche of the body, yet trying to negotiate the relationship between scent and personhood is an uncommon practice in Western society. Ursitti's "sketches" explore the realm of that which has been generally excluded from culture, which is practically beyond signification, which resists culturally intelligible forms of meaning, mapping and knowing. Ursitti challenges the two primary means by which the self is constituted via communication with others: linguistically, through dialogue, narrative, interpellation, etc. (G. H. Mead, Habermas, Althusser), and visually, through the gaze, face-to-face encounters, etc. (Sartre, Lacan, Berger and Luckman). Instead, she offers an example of what it might be like to imagine an alternative model - an olfactory recognition. For Sartre,

When we smell another's body, it is that body itself that we are breathing in through our mouth and nose, that we possess instantly, as it were in its most secret substance, its very nature. Once inhaled, the smell is the fusion of the other's body and my own. But it is a disincarnate body, a vaporised body that remains whole and entire of itself while at the same time becoming a volatile spirit. (qtd. in Le Guérer 24)

Interacting with such volatile spirits, however, can easily entail fear, even danger. The abject plays no small part in the difficulty of regarding Ursitti's olfactory self-portraits. Body odour expands beyond the corporeal limits of the body - it is, in other words, detachable - yet still retains a connection to the body. Part of the dread of body odour lies in the latent persistence of the theory of miasma, that pre-Pasteur belief that smells themselves carry pestilence and disease. Another is the fact that smells do not respect borders - either spatially, by permeating the atmosphere throughout the gallery, or corporeally, by traversing the boundaries of our own bodies. They perform the arch characteristic of the abject: they threat- 
en to defile and engulf us. They are ambiguously object and subject, yet also neither. The horror of body odour, as in the abject, is that our skin cannot guarantee "the integrity of one's 'own and clean self"" (Kristeva 53).

Despite the ability of smell to repulse and defy traditional notions of identity, the possession of an "odour signature" also carries with it allusions of intimidation. In Untitled (1995), a performance in Possil Park, Glasgow executed with the assistance of the Strathclyde Police Department, Ursitti had herself tracked down by a police bloodhound. The performance illustrates the fact that not only does each person exude an individualistic aroma, but each also leaves "odour tracks" of their travelings and whereabouts. The body, as Donna Haraway posited, does not have to end at the skin; indeed, it lingers in the landscape for a surprising length of time (178). Our odour persists, sometimes for weeks, waiting for anyone or anything with the sensitivity to detect it.

While the video documentation of the performance radiates a playful innocence (like an interspecies game of hide-and-seek) as the dog sniffs its way across a field, through bushes, and ultimately finds the artist stationed behind a tree, the activity nevertheless evokes the tabloid sensibilities of murder mysteries, the dramatic chase scenes of detective films or, more ominously, the abuses of a police state. The uniqueness of one's olfactory identity, notwithstanding its ability to exceed the limits of technology for the time being, can easily be appropriated by the state as a tool of identification and enforcement. The unspoken term in this tracking demonstration is "criminal," and the crowd of uniforms surrounding the artist at the finale recalls less the liberating quality of transgression celebrated by Jean Genet, for instance, than the restrictions and outlaw status that could all too easily be placed upon creative or atypical individuals. Perhaps if the gender dynamics weren't so lopsided - male officers, female target - one might know whether the rounds of congratulation offered at the exercise's successful conclusion were for the renegotiation or reinforcement of the questionable cultural valence already infusing the term "scent of a woman" (see my and Fisher's "In the Garden of Nirvana").

This ambivalence is strategic in Ursitti's olfactory self-portraits and performances for it replicates the contradictory status of smell in Western culture. Disdained yet unexpectedly useful, ignored yet subtly influential, cryptic yet immediately experienced, abstract yet intensely powerful, scents elicit a profound diversity of reactions. While it may be beyond the ability of any artwork to convert odorphobia to its opposite, olfactophilia, 
it is possible to underscore smell's meaningfulness. Ursitti's fragrant artistic practice offers potent occasions to sniff and reflect upon the charged position of odour that permeates identity and society.

\section{Works Cited}

Brownmiller, Susan. Femininity. New York: Fawcett-Columbine, 1984.

Classen, Constance, et al. Aroma: The Cultural History of Smell. London; New York: Routledge, 1994.

Corbin, Alain. The Foul and the Fragrant: Odor and the French Social Imagination. Cambridge, MA: Harvard UP, 1986.

Davis, Ann. "The Brave New World of Biometrics." Montreal Gazette 20 Sept. 1997: B1-B2.

Drobnick, Jim. "Inhaling Passions: Art, Sex and Scent." Sexuality and Culture 4.3 (Summer 2000): 37-56.

-. "Reveries, Assaults and Evaporating Presences: Olfactory Dimensions in Contemporary Art." Parachute 89 (1998): 10-19.

Drobnick, Jim, and Jennifer Fisher. "In the Garden of Nirvana: An Interview with Noritoshi Hirakawa." Parachute 88 (1997): 30-35.

Engen, Trygg. Odor Sensation and Memory. New York; Westport, London: Praeger, 1991.

Ensler, Eve. The Vagina Monologues. New York: Villard Books, 1998. Forti, Simone. Angel. New York: n.pub., 1978.

Foucault, Michel. "The Subject and Power." Michel Foucault: Beyond Structuralism and Hermeneutics. Ed. H.L. Dreyfus and P. Rabinow. Chicago: U of Chicago P, 1983. 208-26.

Greer, Germaine. The Madwoman's Underclothes: Essays and Occasional Writings 1968-85. London: Pan Books, 1987.

Haraway, Donna J. Simians, Cyborgs, and Women: The Reinvention of Nature. New York: Routledge, 1991.

Hoffman, Jan. "How They Keep It." New York Times Magazine 19 Nov. 1995: 104.

Hoy, Suellen. Chasing Dirt: The American Pursuit of Cleanliness. New York; Oxford: Oxford UP, 1995.

Hughes, Holly. "World Without End." Out From Under: Texts by Women Performance Artists. Ed. Leonora Champagne. New York: Theatre Communications Group, 1990. 
Independent Curators Incorporated. The Sense of Self: From Self-Portrait to Autobiography. Washington; New York: Independent Curators Incorporated, 1978.

Jones, Amelia. "The 'Sexual Politics' of The Dinner Party: A Critical Context." Sexual Politics: Judy Chicago's Dinner Party in Feminist Art History. Ed. Amelia Jones. Berkeley: U of California P and UCLA at the Armand Hammer Museum of Art and Cultural Center, 1996. 82-118.

Kristeva, Julia. Powers of Horror: An Essay on Abjection. New York: Columbia UP, 1982.

Le Guérer, Annick. Scent: The Mysterious and Essential Powers of Smell. Trans. Richard Miller. New York: Random House, 1992.

McLuhan, Marshall. "How Not to Offend." The Mechanical Bride: Folklore of Industrial Man. Boston: Beacon, 1951. 60-62.

Phelan, Peggy. Unmarked: The Politics of Performance. London: Routledge, 1993.

Sacks, Oliver. "The Dog Beneath the Skin." The Man Who Mistook His Wife for a Hat and Other Clinical Tales. New York: Harper and Row, 1987.

Schleidt, Margret. "The Semiotic Relevance of Human Olfaction: A Biological Approach." Fragrance: The Psychology and Biology of Perfume. Ed. S. Van Toller and G. H. Dodd. London: Elsevier Applied Science, 1992. 37-50.

Schneemann, Carolee. "Parts of a Body House." Fantastic Architecture. Ed. Wolf Vostell and Dick Higgins. Barton, VT: Something Else Press, 1969.

Sontag, Susan. Illness as Metaphor. New York: Random House, 1978.

Süskind, Patrick. Perfume: The Story of a Murderer. Trans. John E. Woods. New York: Pocket Books, 1987.

Synnott, Anthony. The Body Social. New York: Routledge, 1993.

Ursitti, Clara. Artist's statement. Maikäfer flieg, Cologne: Hochbunker Köln-Ehrenfeld, 1995.

-. Email to the Author. 6 July 1998.

-. Interview. Montreal, Quebec. 3 Jan. 1998.

Vroon, Piet. Smell: The Secret Seducer. Trans. Paul Vincent. New York: Farrar, Straus and Giroux, 1997.

Wolff, Janet. "Reinstating Corporeality: Feminism and Body Politics." Feminine Sentences. Berkeley: U of California P, 1990. 